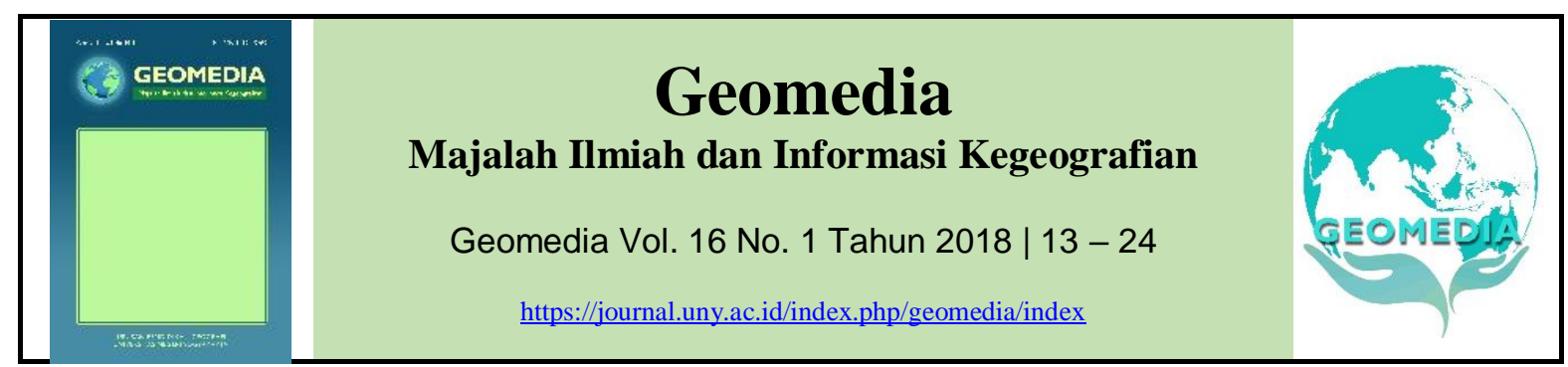

\title{
Kajian pengembangan pusat pertumbuhan wilayah di Kabupaten Klaten
}

\author{
Zenza Wismoyo Ancok ${ }^{1^{*}}$, Nurhadi ${ }^{2}$ \\ a Jurusan Pendidikan Geografi Fakultas IImu Sosial Universitas Negeri Yogyakarta \\ 1 12405244028@student.uny.ac.id*; nurhadi_fise@uny.ac.id; \\ *korespondensi penulis
}

\begin{tabular}{ll}
\hline Informasi artikel & A B S T R A K \\
\hline Kata kunci: & Penelitian ini bertujuan: (1) Menentukan kecamatan pusat pertumbuhan \\
Pusat pertumbuhan & berdasarkan aspek aksesibilitas lokasi, ketersediaan fasilitas pelayanan \\
Sektor basis & publik, potensi penduduk dan keterkaitan wilayah, (2) Mengetahui \\
Pengembangan wilayah & karakteristik sektor basis beserta keunggulannya di pusat pertumbuhan, \\
RTRW & (3) Memberikan arahan pengembangan pusat-pusat pertumbuhan di \\
& Kabupaten Klaten dalam mendukung kegiatan pengembangan wilayah, \\
& (4) Membandingan kesesuaian arahan pengembangan dengan RTRW \\
& Kabupaten Klaten. Populasi penelitian ini adalah seluruh kecamatan di \\
& Kabupaten Klaten. Pengumpulan data dengan observasi dan \\
& dokumentasi. Analisis data menggunakan analisis scalogram, indeks \\
& sentralitas marshall, potensi penduduk, keterkaitan wilayah keruangan \\
& dan analisis kebijakan. Hasil penelitian: (1) Kecamatan Klaten Selatan, \\
& Klaten Tengah dan Klaten Utara yang merupakan perkotaan Klaten \\
menjadi pusat pertumbuhan utama, diarahkan untuk pengembangan & sektor jasa dan sektor perdagangan; (2) hasil analisis sektor basis dengan \\
menggunakan metode LQ (Location Quotient) diperoleh dua prioritas \\
pengembangan wilayah yaitu pertanian di 16 kecamatan dan industri di 9 \\
kecamatan; (3) arahan pengembangan meliputi tiga wilayah \\
pengembangan yaitu pusat pertumbuhan utama, pusat pertumbuhan \\
alternatif dan hinterland; (4) arahan kesesuaian pengembangan wilayah \\
dengan RTRW menunjukkan 13 Kecamatan memiliki kesesuaian dengan \\
RTRW sedangkan satu kecamatan tidak sesuai.
\end{tabular}

\section{Keywords:}

Growth center

Basis sector

Regional development

Spatial policy

\section{A B S T R A C T}

This study aims to: (1) Determine the growth centers based on aspects of location accessibility, availability of public service, potential population and regional interelation, (2) knowing the characteristics of the base sector and their superiority in growth centers, (3) Provide the development steps of growth centers in Klaten district in supporting regional development, (4) Comparing the suitability of the development direction with the Klaten District Spatial Plan. The population of this study is all sub-districts in Klaten District. The data collection has done by observation and documentation. Data analysis employ scalogram analysis, Marshall centrality index, population potential, spatial interelation and policy analysis. The result of this research : (1) Klaten Selatan, Klaten Tengah and Klaten Utara sub-districts which are Klaten cities are the main growth centers, service and trade is a sector that can be developed in this region; (2) the results of the base sector analysis using the LQ (Location Quotient) method obtained two regional development priorities, namely agriculture in 16 sub-districts and industries in 9 sub-districts; (3) development directions based on this research include three development areas namely the main growth centers, alternative growth centers and hinterland; (4) the direction of the suitability of the development of the region with the spatial planning shows that 13 sub-districts are in conformity with the spatial plan, while one sub-district is not suitable. 


\section{Pendahuluan}

Pembangunan wilayah memiliki peranan penting terhadap pemerataan ekonomi masyarakat. Pengembangan wilayah merupakan upaya pemerintah dalam melakukan pembangunan wilayah. Pengembangan wilayah adalah upaya lanjut dari pembangunan yang merupakan proses pengelolaan sumberdaya secara terus menerus untuk mencapai perkembangan wilayah dan kesejahteraan masyarakat didalamnya secara seimbang dengan melibatkan semua elemen masyarakat untuk mencapai tujuan pembangunan dan keberlanjutan (Muta'ali, 2014: 121). Pembangunan wilayah harus didukung dengan kemampuan dari masingmasing daerah untuk menghindari terjadinya ketimpangan perkembangan wilayah. Hal ini karena dampak pembangunan kenyataannya menimbulkan kesenjangan pemerataan ekonomi di berbagai wilayah dan merupakan suatu permasalahan yang bersifat universal.

Potensi dan permasalahan yang dimiliki oleh setiap wilayah sangat berbeda-beda. Karakteristik wilayah di Indonesia memiliki ciri-ciri spasial. Kabupaten Klaten merupakan salah satu contoh wilayah di Jawa Tengah yang mengalami permasalahan pembangunan sehingga berdampak pada kesenjangan ekonomi masyarakat. Data PDRB Kabupaten tahun 2012, menunjukkan 39\% daerah di Kabupaten Klaten mengalami defisit pertumbuhan PDRB (BPS Kabupaten Klaten, 2013). Kondisi ini diperkirakan karena adanya pemusatan kegiatan ekonomi khususnya industri dan perdagangan di beberapa wilayah kecamatan di Kabupaten Klaten sehingga terjadi ketimpangan ekonomi. Hal ini menunjukkan bahwa sebagian besar wilayah di Kabupaten Klaten belum diperhatikan dengan baik oleh pemerintah daerah. Kecamatan yang dimaksud diantaranya Gantiwarno, Cawas, Kebonarum, Manisrenggo, Karangnongko, Karandowo, Juwiring, Wonosari, Tulung dan Kemalang.

Luas wilayah Kabupaten Klaten tercatat 655,56 Km2 yang meliputi 26 Kecamatan. Kabupaten Klaten diapit oleh daerah-daerah maju dan berkembang yakni Kabupaten Boyolali, Kabupaten Surakarta, dan Provinsi Daerah Istimewa Yogyakarta. Kabupaten Klaten yang berada di Jawa Tengah bagian selatan merupakan jalur penghubung antara Surakarta dengan Yogyakarta. Mobilitas tinggi pada jalur utama penghubung Surakarta-Yogyakarta memberikan dampak terhadap pertumbuhan Kabupaten Klaten baik dari sisi ekonomi, sosial, budaya, pendidikan, maupun aspek lainnya, utamanya pada kecamatan yang dilalui jalur utama seperti Kecamatan Prambanan, Jogonalan, Kecamatan Ceper, Kecamatan Delangu, Kecamatan Klaten Selatan, Kecamatan Klaten Tengah, dan Kecamatan Klaten Utara. Perlu adanya arahan pembangunan yang memperhatikan berbagai aspek.

Pembangunan wilayah berhubungan dengan aksesibilitas. Kecamatan dengan kondisi aksesibilitas baik akan lebih cepat berkembang, sedangkan kecamatan yang aksesibilitasnya rendah akan terhambat perkembangannya. Jalan menjadi faktor penting dalam mempengaruhi aksesibilitas antar wilayah di Kabupaten Klaten maupun kabupaten lainnya. Salah satu indikator yaitu keberadaan jalur arteri yang melintasi Kabupaten Klaten. Kecamatan yang berada jauh dari jangkauan jalur arteri memiliki perbedaan kondisi ekonomi dengan kecamatan yang berada di jalur arteri sebagai pusat pertumbuhan.

Faktor penentu utama pertumbuhan ekonomi suatu daerah adalah berhubungan langsung dengan permintaan akan barang dan jasa dari luar daerah. Berkaitan dengan strategi pengembangan wilayah harus memperhatikan sektor-sektor yang menjadi basis dan non-basis ekonomi disetiap kecamatan. Besar kecilnya sektor basis sebagai penggerak utama perekonomian disetiap kecamatan akan berpengaruh terhadap penyerapan tenaga kerja dan tingkat kesejahteraan. Kecamatan Bayat berada pada tingkat kesejahteraan kategori rendah yaitu sebanyak 9.575 keluarga. Kecamatan Klaten Selatan yang berada di Pusat Kota memiliki jumlah keluarga pra sejahtera paling rendah yaitu 393 keluarga. Kecamatan Klaten Utara memiliki jumlah Keluarga Sejahtera III Plus paling tinggi sebesar 1.785 keluarga dibandingkan dengan Kecamatan Kemalang yang hanya memiliki 12 keluarga sejahtera III+. (Kabupaten Klaten Dalam Angka, 2015:115).

Pertumbuhan wilayah berlangsung akibat keterkaitan antar daerah yang kuat. Keterkaitan wilayah antar kecamatan berpengaruh terhadap pengembangan wilayah di Kabupaten Klaten. Interaksi antar kecamatan di Kabupaten Klaten 
cenderung lemah hanya terbatas pada kegiatankegiatan ekonomi saja. Kecamatan yang memiliki nilai strategis wilayah yang tinggi memiliki daya tarik untuk menjadi pusat pertumbuhan.

Pusat pertumbuhan yang belum mampu memberikan dampak perkembangan ekonomi pada daerah hinterland merupakan persoalan yang muncul akibat adanya disparitas spasial antar wilayah. Kesenjangan pembangunan wilayah dapat diidentifikasi dari ketersediaan fasilitas pelayanan publik. Pengembangan wilayah seharusnya mengacu pada Rencana Tata Ruang Wilayah (RTRW). Berdasarkan Peraturan Pemerintah (1997) tentang Rencana Tata Ruang Wilayah Nasional Presiden Republik Indonesia, menjelaskan bahwa salah satu tujuan nasional Pemanfaatan tata ruang, yaitu meningkatkan keseimbangan dan keserasian perkembangan antar wilayah serta keserasian antar sektor melalui pemanfaatan ruang kawasan secara serasi, selaras dan seimbang serta berkelanjutan.

Kecamatan Klaten Tengah memiliki fasilitas transportasi yang menonjol, terdapat Stasiun Hanacaraka di jalur Surakarta-Yogyakarta dan Terminal IR Soekarno di jalur arteri Kabupaten Klaten. Perbedaan kepemilikan fasilitas pelayanan publik antar kecamatan menimbulkan pengaruh yang besar terhadap daya tarik wilayah untuk menjadi pusat pertumbuhan. Berdasarkan RTRW Kabupaten Klaten 2011-2031 terdapat kesenjangan pertumbuhan wilayah yang signifikan antar kecamatan di Kabupatan Klaten terkait dengan sumberdaya alam dan sumberdaya manusianya.

Kajian mengenai pembangunan wilayah di Kabupaten ini menarik untuk dilakukan, salah satunya dengan menetapkan Kecamatan Pusat Pertumbuhan yang berada di Kabupaten Klaten berdasarkan aksesibilitas wilayah kecamatan, ketersediaan berbagai fasilitas pelayanan publik, potensi penduduk, dan keterkaitan wilayah antar kecamatan. Kajian pengembangan pusat pertumbuhan akan dianalisis secara terpadu untuk menentukan pusat pertumbuhan sehingga diperoleh informasi yang dapat dimanfaatkan sebagai acuan dalam pengembilan kebijakan pembangunan wilayah dan disesuaikan dengan RTRW Kabupaten Klaten. Pusat-pusat pertumbuhan yang akan dikembangkan, mempunyai efek menyebar dan terjadi pemerataan pembangunan di seluruh wilayah.

\section{Metode}

Penelitian ini merupakan penelitian deskriptif dengan pendekatan kuantitatif. Penelitian deskriptif dengan pendekatan kuantitatif ini menggambarkan dan menganalisis tingkat aksesibilitas, fasilitas pelayanan publik, potensi penduduk dan keterkaitan antar wilayah antar kecamatan. Pusat pertumbuhan, sektor basis dan kebijakan daerah yang timbul antar pusat pertumbuhan digunakan sebagai gambaran pengembangan wilayah yang ada di Kabupaten Klaten. Penelitian ini dilakukan dengan cara mengumpulkan dan menganalisis data sekunder dari instansi yang relevan serta didukung oleh pengamatan langsung dilapangan.

Penelitian ini dilaksanakan di Kabupaten Klaten pada bulan November 2016 sampai dengan bulan Agustus 2017. Variabel yang digunakan dalam penelitian ini adalah ketersediaan fasilitas pelayanan publik, potensi penduduk, konektivitas, dan sektor basis. Data dikumpulkan melalui observasi dan dokumentasi. Observasi ini digunakan untuk mendapatkan data primer dengan memperlihatkan fenomena yang nyata dilapangan terutama untuk mengetahui ketersediaan fasilitas sarana dan prasarana di Kabupaten Klaten. Dokumentasi dilakukan untuk memperoleh data dari instansi terkait didukung dengan data dari internet. Data yanf dikumpulkan melalui dokumentasi antara lain (1) data statistik Kabupaten Klaten dari BPS Kabupaten Klaten, (2) data Perda RTRW dan RPJPD Kabupaten Klaten dari Pemda Kabupaten Klaten, serta (3) peta wilayah, database kabupaten, profil kabupaten, data tenaga kerja, dan PAD kabupaten yang diperoleh dari dari BAPPEDA Kabupaten Klaten.

Selanjutnya data yang telah diperoleh dianalisis dengan menggunakan analisis keruangan yaitu meliputi (1) analisis aksesibilitas lokasi, analisis skalogram, analisis indeks sentralitas marshall, potensi penduduk, keterkaitan wilayah, dan location quotient, (2) analisis penetapan pusat pertumbuhan wilayah, dan (3) analisis deskriptif.

Dalam melakukan analisis aksesibilitas lokasi variabel yang digunakan adalah kepadatan jalan. Aksesibilitas lokasi digunakan untuk menunjukkan tingkat strategis suatu lokasi. Analisis skalogram digunakan untuk menghitung tingkat kelengkapan fasilitas kecamatan yang di kelompikkan menjadi dua kelompok, yaitu fasilitas 
yang berkaitan dengan aktivitas ekonomi dan fasilitas yang berkaitan dengan aktivitas sosial. Tahapan metode skalogram adalah: (1) kecamatan diurutkan berdasarkan peringkat jumlah penduduk secara vertikal, jenis fasilitas disusun secara horizontal, fasilitas yang tersedia di setiap wilayah dimasukkan pada tabel yang sesuai kecamatan atau jenis fasilitas, (4) jumlah fasilitas yang tersedia di setiap kecamatan.

Potensi penduduk dihitung dengan pada data jumlah penduduk dan data jarak antar tempat/titik berdasarkan jalur transportasi (Bintarto dan Surastopo, 1979). Keterkaitan wilayah dalam penelitian ini menggunakan nilai indek sentralitas wilayah yang menunjukkan nilai strategis wilayah berdasarkan aspek lokasi geografis, dimana wilayah tersebut dicirikan dengan kemudahan akses dan banyaknya link dan simpul trasnportasi yang mengumpul pada wilayah tersebut. Wilayah yang memiliki nilai sentralis tinggi merupakan pusat orientasi kegiatan dan menjadi wilayah tujuan.

Penentuan nilai indek sentralis wilayah berdasarkan nilai konig dan simbel. Konig (K), yaitu jumlah maksimum keterhubungan antara satu wilayah dengan wilayah lain (Gambar 1). Wilayah A memiliki nilai konig 5 khususnya dengan wilayah $H$, yaitu untuk menuju wilayah $H$ dari wilayah A harus menempuh 5 jalur keterhubungan. Simbel (S), yaitu jumlah keterhubungan suatu wilayah dengan wilayah lain, dimana nilai simbel terendah adalah $\mathrm{J}$ sehingga berarti wilayah $\mathrm{J}$ paling mudah dan cepat dijangkau oleh wilayahwilayah lainnya.
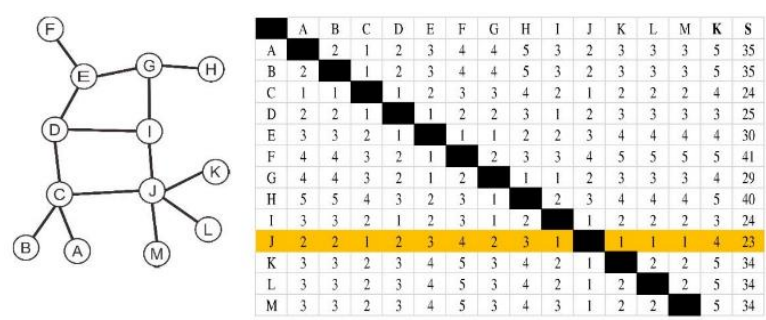

Gambar 1. Ilustrasi rute terdekat dan jumlah rute antar wilayah. $\mathrm{K}=\mathrm{Konig}, \mathrm{S}=\mathrm{Simbel}$

Analisis LQ digunakan untuk menentukan keberadaan sektor basis dan non basis. Nilai LQ di dasarkan pada jumlah tenaga kerja yang terserap pada sektor tersebut di setiap pusat pertumbuhan di Kabupaten Klaten, mengacu kepada Muta'ali (2015: 91).

\section{Hasil dan pembahasan Daerah Penelitian}

Kabupaten Klaten merupakan salah satu kabupaten di Provinsi Jawa Tengah yang secara geografis terletak antara $110^{0} 26^{\prime} 14^{\prime \prime}-110^{\circ} 48^{\prime} 33^{\prime \prime}$ BT serta 7032'19'-7048'33' LS. Letak Kabupaten Klaten cukup strategis karena berbatasan langsung dengan kota Surakarta dan Daerah Istimewa Yogyakarta. Secara administratif Kabupaten Klaten dibatasi di sebelah utara oleh Kabupaten Boyolali (Jawa Tengah), sebelah timur Kabupaten Sukoharjo (Jawa Tengah), sebelah selatan Kabupaten Gunungkidul (DI Yogyakarta), dan sebelah barat Kabupaten Sleman (DI Yogyakarta). Kabupaten Klaten terdiri atas 26 kecamatan dengan luas wilayah $655,56 \mathrm{Km}^{2}$ (Gambar 1). Kondisi Topografi wilayah Kabupaten Klaten diapit oleh Gunung Merapi dan Pegunungan Seribu dengan ketinggian antara 76 - 1.600 mdpl. Keadaan iklim Kabupaten Klaten termasuk iklim tropis dengan curah hujan selama tahun 2015 sebesar 83,179 $\mathrm{mm}$. penggunaan Iahan paling dominan adalah untuk sawah yang merupakan daerah pertanian dengan luas $33.111 \mathrm{Ha}$ atau $50,42 \%$ dari keseluruhan luas wilayah Kabupaten Klaten. Lahan untuk pertanian yang masih luas dapat dimanfaatkan untuk meningkatkan pendapatan dari sektor pertanian. Penggunaan lahan untuk permukiman sebesar $20.317 \mathrm{Ha}$ atau $30,94 \%$ dari total luas wilayah Kabupaten Klaten. permukiman yang ada di Kabupaten Klaten memiliki pola menyebar di seluruh wilayah. Tegalan dan hutan masing-masing memiliki luas $6.354 \mathrm{Ha}$ dan $1.450 \mathrm{Ha}$ dimana penggunaan lahan untuk tegalan mencapai $9,68 \%$ dan untuk hutan mencapai 2,21\% dari total luas wilayah Kabupaten Klaten. Gambar 2 menunjukkan penggunaan lahan di Kabupaten Klaten.

Jumlah penduduk Kabupaten Klaten menurut berdasarkan data BPS (2015) sebanyak 1.158.795 jiwa. Kecamatan dengan jumlah penduduk terbanyak adalah Kecamatan Trucuk dengan jumlah penduduk 70.601 jiwa sedangkan yang paling sedikit adalah Kebonarum yaitu 17.879 jiwa. Kepadatan Penduduk tertinggi dijumpai di Kecamatan Klaten Tengah yang merupakan bagian dari ibukota Kabupaten Klaten yaitu sebesar 4.489 jiwa $/ \mathrm{km}^{2}$ sedangkan kepadatan penduduk terendah dijumpai di Kecamatan Kemalang yaitu 692 jiwa $/ \mathrm{km}^{2}$. 


\section{PETA ADMINISTRATIF KABUPATEN KLATEN}

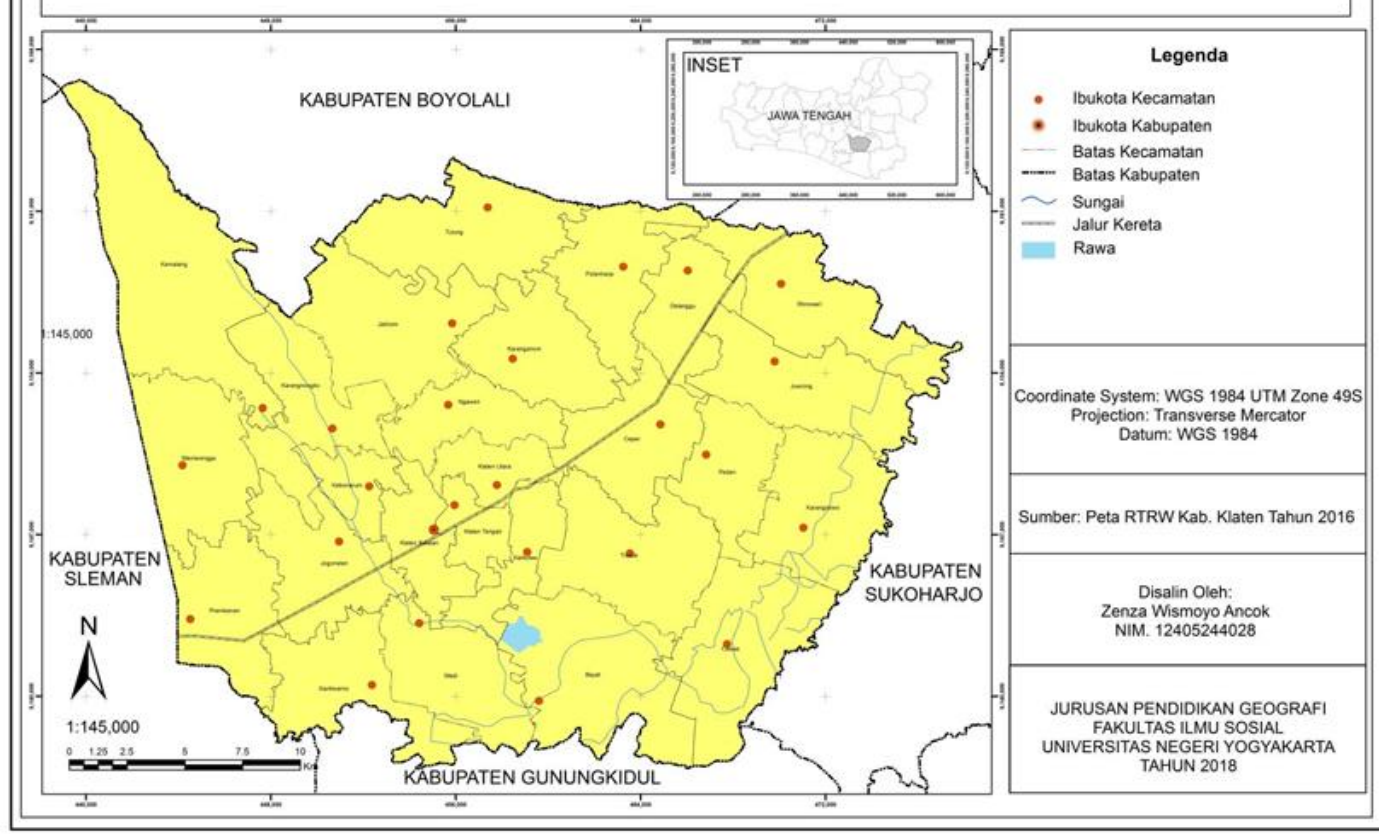

Gambar 1. Peta administratif Kabupaten Klaten

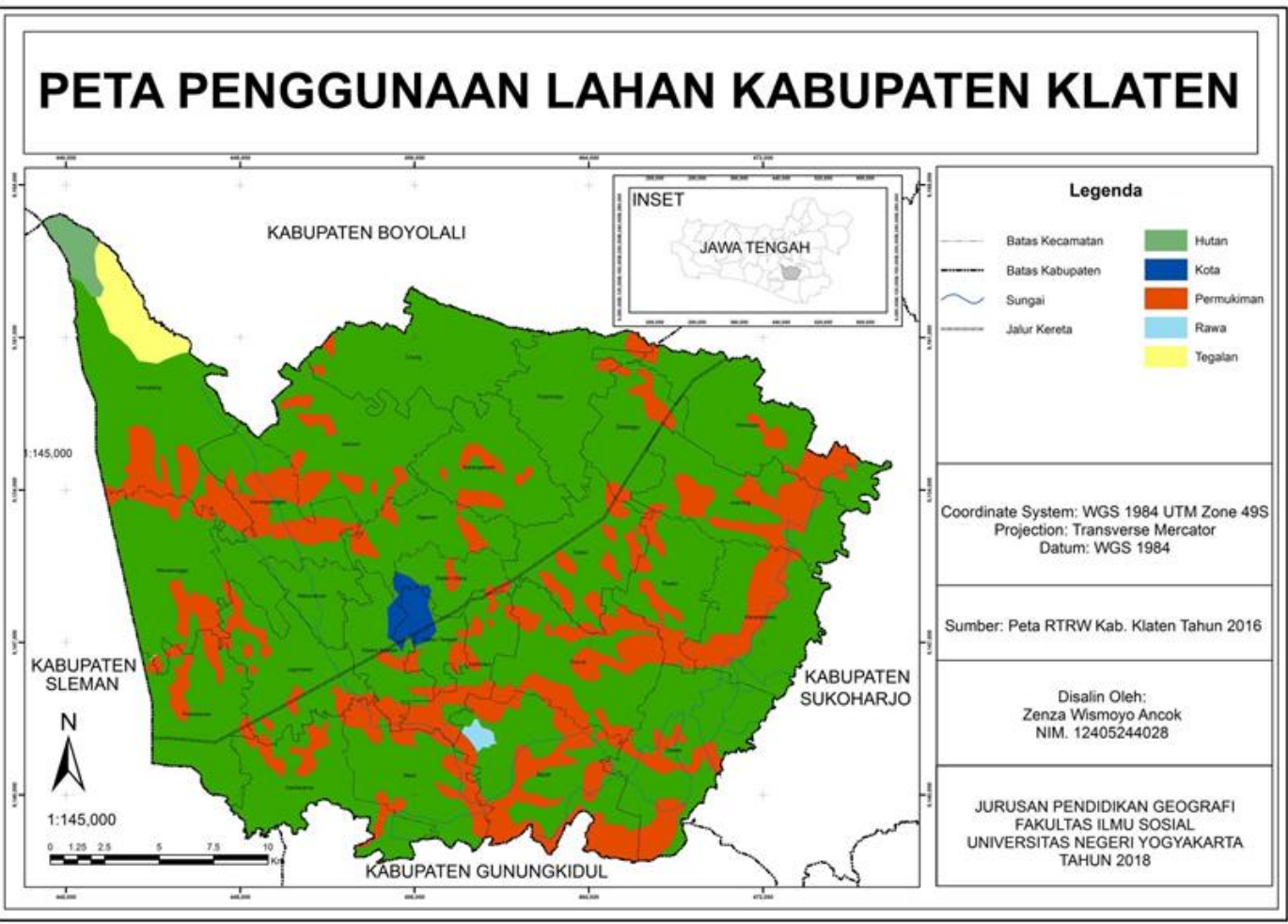

Gambar 2. Peta Penggunaan Lahan Kabupaten Klaten

\section{Aksesibilitas Lokasi}

Tingkat aksesibilitas dalam penelitian ini berdasarkan panjang jalan dan jumlah jalan yang terdapat pada tiap kecamatan terhadap luas kecamatan di Kabupaten Klaten. Tingkat aksesibilitas sangat berpengaruh dalam penentuan pusat pertumbuhan, yaitu semakin tinggi aksesibilitas pada suatu wilayah maka akan diikuti dengan kecenderungan perkembangan wilayah yang semakin cepat. Terdapat tiga jenis 
jalan yang digunakan yaitu jalan arteri, jalan kolektor, dan jalan lokal sehingga dapat digunakan untuk menghitung kepadatan jalan di Kabupaten Klaten.

Berdasarkan hasil penghitungan diketahui bahwa wilayah dengan nilai skor aksesibilitas tinggi merupakan wilayah yang cenderung memiliki tingkat perkembangan yang lebih tinggi, sedangkan daerah dengan nilai skor rendah tergolong mengarah pada wilayah dengan tingkat perkembangan tertinggal. Hasil analisis tersebut selanjutnya dikalikan nilai bobot untuk tingkat aksesibilitas yaitu sebesar 20\%. Skor hasil penghitungan tingkat aksesibilitas masing-masing Kecamatan di Kabupaten Klaten ditunjukkan oleh Tabel 1.

Tabel 1. Nilai tingkat akesibilitas masing-masing kecamatan di Kabupaten Klaten

\begin{tabular}{|c|c|c|c|c|}
\hline No & Kecamatan & Nilai & Bobot & Score \\
\hline 1 & Prambanan & 33,83 & 0,20 & 6,77 \\
\hline 2 & Gantiwarno & 29,88 & 0,20 & 5,98 \\
\hline 3 & Wedi & 24,94 & 0,20 & 4,99 \\
\hline 4 & Bayat & 19,26 & 0,20 & 3,85 \\
\hline 5 & Cawas & 33,09 & 0,20 & 6,62 \\
\hline 6 & Trucuk & 45,19 & 0,20 & 9,04 \\
\hline 7 & Kalikotes & 42,22 & 0,20 & 8,44 \\
\hline 8 & Kebonarum & 37,78 & 0,20 & 7,56 \\
\hline 9 & Jogonalan & 29,14 & 0,20 & 5,83 \\
\hline 10 & Manisrenggo & 25,43 & 0,20 & 5,09 \\
\hline 11 & Karangnongko & 29,88 & 0,20 & 5,98 \\
\hline 12 & Ngawen & 33,83 & 0,20 & 6,77 \\
\hline 13 & Ceper & 33,83 & 0,20 & 6,77 \\
\hline 14 & Pedan & 38,77 & 0,20 & 7,75 \\
\hline 15 & Karangdowo & 19,75 & 0,20 & 3,95 \\
\hline 16 & Juwiring & 22,96 & 0,20 & 4,59 \\
\hline 17 & Wonosari & 29,88 & 0,20 & 5,98 \\
\hline 18 & Delanggu & 40,25 & 0,20 & 8,05 \\
\hline 19 & Polanharjo & 26,42 & 0,20 & 5,28 \\
\hline 20 & Karanganom & 24,69 & 0,20 & 4,94 \\
\hline 21 & Tulung & 31,11 & 0,20 & 6,22 \\
\hline 22 & Jatinom & 44,44 & 0,20 & 8,89 \\
\hline 23 & Kemalang & 22,47 & 0,20 & 4,49 \\
\hline 24 & Klaten Selatan & 69,38 & 0,20 & 13,88 \\
\hline 25 & Klaten Tengah & 100 & 0,20 & 20,00 \\
\hline 26 & Klaten Utara & 80,99 & 0,20 & 16,20 \\
\hline
\end{tabular}

Sumber: hasil analisis, 2017

\section{Skalogram dan index sentralitas}

Analisis skalogram digunakan untuk mengetahui kemampuan dan peran suatu kecamatan untuk menyediakan berbagai fasilitas kepada masyarakat. Perhitungan fasilitas didasarkan kepada banyaknya fasilitas yang dimiliki tiap-tiap kecamatan. Nilai fasilitas umum tersebut digunakan untuk menentukan kecamatan yang dapat berperan sebagai pusat pertumbuhan.

Hasil analisis menunjukkan bahwa diantara 26 kecamatan di Kabupaten Klaten, Kecamatan Klaten Tengah memiliki skor paling tinggi. Skor tinggi ini diperoleh dari banyaknya fasilitas umum yang tersedia serta diikuti dengan lokasi yang sangat strategis yaitu di pusat kota pada jalan arteri Yogyakarta - Surakarta. Dari segi fasilitas pendidikan Kecamatan Klaten Tengah berada pada peringkat 9 dibanding kecamatan lain, dari segi fasilitas kesehatan berada pada peringkat ke2 setelah Kecamatan Delanggu, dari segi fasilitas ekonomi merupakan yang tertinggi di Kabupaten Klaten, dan dari segi fasilitas transportasi merupakan peringkat ke-3.

\section{Potensi penduduk}

Potensi penduduk merupakan analisis untuk menggambarkan tingkat potensi suatu daerah untuk berkembang. Potensi penduduk digunakan untuk penentuan pusat pertumbuhan di setiap kecamatan berdasarkan kemampuan mobilitas penduduk di wilayah tersebut ke wilayah lain. Semakin dekat jarak antar kecamatan dan semakin besar jumlah penduduk maka nilai potensi penduduk akan semakin besar. Hasil penghitungan potensi penduduk ditunjukkan oleh Tabel 2.

\section{Keterkaitan wilayah}

Keterkaitan wilayah dalam penelitian ini digunakan untuk menunjukkan nilai strategis suatu wilayah yang dipengaruhi oleh jarak antar wilayah kecamatan dalam Kabupaten Klaten. Semakin strategis suatu wilayah maka semakin mudah untuk menjangkau kecamatan lain dalam Kabupaten Klaten. Keterkaitan yang tinggi dapat memberikan kemudahan untuk berinteraksi dengan wilayah lain. Semakin tinggi interaksi suatu wilayah maka wilayah tersebut cocok untuk dijadikan pusat pertumbuhan. Hasil penghitungan potensi penduduk ditunjukkan oleh Tabel 3. 
Tabel 2. Hasil Analisis Potensi Penduduk Kabupaten Klaten

\begin{tabular}{|c|c|c|c|c|}
\hline No & Kecamatan & Penduduk & Nilai & Score \\
\hline 1 & Prambanan & 5.860 & 11,77 & 2,35 \\
\hline 2 & Gantiwarno & 10.500 & 21,09 & 4,22 \\
\hline 3 & Wedi & 23.619 & 47,43 & 9,49 \\
\hline 4 & Bayat & 8.396 & 16,86 & 3,37 \\
\hline 5 & Cawas & 7.786 & 15,64 & 3,13 \\
\hline 6 & Trucuk & 10.165 & 20,41 & 4,08 \\
\hline 7 & Kalikotes & 26.568 & 53,36 & 10,67 \\
\hline 8 & Kebonarum & 44.034 & 88,44 & 17,69 \\
\hline 9 & Jogonalan & 34.185 & 68,65 & 13,73 \\
\hline 10 & Manisrenggo & 6.078 & 12,21 & 2,44 \\
\hline 11 & Karangnongko & 16.254 & 32,64 & 6,53 \\
\hline 12 & Ngawen & 28.201 & 56,64 & 11,33 \\
\hline 13 & Ceper & 14.460 & 29,04 & 5,81 \\
\hline 14 & Pedan & 14.204 & 28,53 & 5,71 \\
\hline 15 & Karangdowo & 7.517 & 15,09 & 3,02 \\
\hline 16 & Juwiring & 9.592 & 19,26 & 3,85 \\
\hline 17 & Wonosari & 10.388 & 20,86 & 4,17 \\
\hline 18 & Delanggu & 14.550 & 29,22 & 5,84 \\
\hline 19 & Polanharjo & 10.031 & 20,14 & 4,03 \\
\hline 20 & Karanganom & 18.889 & 37,93 & 7,59 \\
\hline 21 & Tulung & 6.600 & 13,26 & 2,65 \\
\hline 22 & Jatinom & 17.926 & 36,00 & 7,20 \\
\hline 23 & Kemalang & 13.084 & 26,28 & 5,26 \\
\hline 24 & Klaten Selatan & 42.612 & 85,58 & 17,12 \\
\hline 25 & Klaten Tengah & 49.793 & 100 & 20,00 \\
\hline 26 & Klaten Utara & 26.389 & 53,00 & 10,60 \\
\hline
\end{tabular}

\section{Pusat pertumbuhan}

Penentuan pusat pertumbuhan dalam penelitian beberapa unit analisis meliputi tingkat aksesibilitas, skalogram, potensi penduduk dan keterkaitan wilayah. Hasil dari skor pusat pertumbuhan dikelompokkan dengan memberikan hirarki. Pembagian wilayah dalam tiga hirarki sesuai total score bertujuan untuk mempermudah dalam menganalisis dan memberikan arahan pengembangan. Hirarki I adalah pusat pertumbuhan utama, Hirarki 2 adalah pusat pertumbuhan alternatif, dan hirarki III adalah hinterland. Pembagian kecamatan sesuai hirarki dilakukan dengan menjumlahkan score tiap unit. Hasil dari penjumlahan yang telah dihiraki kemudian jelaskan penyebab perkembangan wilayah yang berbeda sesuai tingkat analisis, skalogram, fasilitas umum, dan keterkaitan wilayah daerah tersebut. Hirarki Kecamatan di Kabupaten
Klaten berdasarkan hasil analisis Pusat Pertumbuhan ditunjukkan oleh Tabel 4. Persebaran spasial hirarki kecamatan ditunjukkan oleh Gambar 3.

Tabel 3. Keterkaitan wilayah di Kabupaten Klaten

\begin{tabular}{|c|c|c|c|c|c|}
\hline \multirow{3}{*}{$\begin{array}{l}\text { No } \\
1\end{array}$} & \multirow{3}{*}{$\begin{array}{c}\text { Kecamatan } \\
\text { Prambanan }\end{array}$} & \multirow{2}{*}{\multicolumn{2}{|c|}{$\begin{array}{c}\begin{array}{c}\text { Keterkaitan } \\
\text { Wilayah }\end{array} \\
\text { Konig Simbel }\end{array}$}} & \multirow{3}{*}{$\begin{array}{l}\text { Nilai } \\
13,49\end{array}$} & \multirow{3}{*}{$\begin{array}{l}\text { Score } \\
2,02\end{array}$} \\
\hline & & & & & \\
\hline & & 7 & 91 & & \\
\hline 2 & Gantiwarno & 6 & 81 & 35,12 & 5,27 \\
\hline 3 & Wedi & 5 & 62 & 67,21 & 10,08 \\
\hline 4 & Bayat & 4 & 63 & 76,05 & 11,40 \\
\hline 5 & Cawas & 5 & 71 & 56,74 & 8,51 \\
\hline 6 & Trucuk & 4 & 57 & 83,02 & 12,45 \\
\hline 7 & Kalikotes & 4 & 61 & 78,37 & 11,76 \\
\hline 8 & Kebonarum & 5 & 69 & 59,07 & 8,86 \\
\hline 9 & Jogonalan & 5 & 63 & 66,05 & 9,91 \\
\hline 10 & Manisrenggo & 6 & 79 & 37,44 & 5,62 \\
\hline 11 & Karangnongko & 4 & 59 & 80,70 & 12,10 \\
\hline 12 & Ngawe & 3 & 51 & 100,00 & 15,00 \\
\hline 13 & Ceper & 4 & 55 & 85,35 & 12,80 \\
\hline 14 & Pedan & 5 & 66 & 62,56 & 9,38 \\
\hline 15 & Karangdowo & 6 & 82 & 33,95 & 5,09 \\
\hline 16 & Juwiring & 6 & 83 & 32,79 & 4,92 \\
\hline 17 & Wonosari & 7 & 92 & 12,33 & 1,85 \\
\hline 18 & Delanggu & 6 & 71 & 46,74 & 7,01 \\
\hline 19 & Polanharjo & 6 & 70 & 47,91 & 7,19 \\
\hline 20 & Karanganom & 4 & 61 & 78,37 & 11,76 \\
\hline 21 & Tulung & 5 & 75 & 52,09 & 7,81 \\
\hline 22 & Jatinom & 4 & 66 & 72,56 & 10,88 \\
\hline 23 & Kemalang & 6 & 85 & 30,47 & 4,57 \\
\hline 24 & Klaten Selatan & 4 & 57 & 83,02 & 12,45 \\
\hline 25 & Klaten Tengah & 4 & 69 & 69,07 & 10,36 \\
\hline 26 & Klaten Utara & 4 & 53 & 87,67 & 13,15 \\
\hline
\end{tabular}

Pusat pertumbuhan utama di Kabupaten Klaten terdapat di kawasan perkotaan Klaten (Kecamatan Klaten Selatan, Kecamatan Klaten Tengah dan Kecamatan Klaten Utara). Kecamatan tersebut didukung dengan faktor tingkat aksesibilitas, fasilitas umum, potensi penduduk tertinggi di Kabupaten Klaten. Pusat pertumbuhan alternatif di Kabupaten Klaten terdapat di Kecamatan Wedi, Bayat, Cawas, Trucuk, Kalikotes, Jogonalan, Ngawen, Ceper, Delanggu, Karanganom, Tulung, dan Jatinom. Kecamatan tersebut mampu melayani kegiatan ekonomi antar wilayah kecamatan dan 
berpotensi menjadi pusat pertumbuhan baru. Kecamatan yang termasuk dalam hinterland di Kabupaten Klaten diantaranya adalah Kecamatan Prambanan, Gantiwarno, Kebonarum,

Karangdowo, Juwiring, Wonosari, Polanharjo, dan Kemalang. Kecamatan dengan jarak paling jauh dengan pusat pertumbuhan utama adalah Manisrenggo, Karangnongko, Pedan, Kecamtan Kemalang.

Tabel 4. Hirarki Kecamatan di Kabupaten Klaten

\begin{tabular}{|c|l|c|c|c|c|c|c|}
\hline No. & Kecamatan & $\begin{array}{c}\text { Tingkat } \\
\text { Akses }\end{array}$ & Skalogram & Potensi & $\begin{array}{c}\text { Ket. } \\
\text { Wilayah }\end{array}$ & Total & Hirarki \\
\hline 1 & Prambanan & 6,77 & 33,54 & 2,35 & 3,02 & 45,68 & III \\
\hline 2 & Gantiwarno & 5,98 & 26,07 & 4,22 & 4,77 & 41,04 & III \\
\hline 3 & Wedi & 4,99 & 33,49 & 9,49 & 10,58 & 58,55 & II \\
\hline 4 & Bayat & 3,85 & 37,24 & 3,37 & 12,91 & 57,37 & II \\
\hline 5 & Cawas & 6,62 & 41,55 & 3,13 & 9,01 & 60,31 & II \\
\hline 6 & Trucuk & 9,04 & 44,40 & 4,08 & 13,95 & 71,47 & II \\
\hline 7 & Kalikotes & 8,44 & 22,99 & 10,67 & 13,26 & 55,36 & II \\
\hline 8 & Kebonarum & 7,56 & 13,37 & 17,69 & 9,36 & 47,98 & III \\
\hline 9 & Jogonalan & 5,83 & 37,49 & 13,73 & 10,41 & 67,46 & II \\
\hline 10 & Manisrenggo & 5,09 & 25,22 & 2,44 & 5,12 & 37,87 & III \\
\hline 11 & Karangnongko & 5,98 & 22,01 & 6,53 & 13,60 & 48,12 & III \\
\hline 12 & Ngawen & 6,77 & 29,66 & 11,33 & 15,00 & 62,76 & II \\
\hline 13 & Ceper & 6,77 & 39,59 & 5,81 & 14,30 & 66,47 & II \\
\hline 14 & Pedan & 7,75 & 27,92 & 5,71 & 9,88 & 51,26 & III \\
\hline 15 & Karangdowo & 3,95 & 24,32 & 3,02 & 4,59 & 35,88 & III \\
\hline 16 & Juwiring & 4,59 & 36,43 & 3,85 & 4,42 & 49,29 & III \\
\hline 17 & Wonosari & 5,98 & 35,51 & 4,17 & 2,85 & 48,51 & III \\
\hline 18 & Delanggu & 8,05 & 35,96 & 5,84 & 6,51 & 56,36 & II \\
\hline 19 & Polanharjo & 5,28 & 25,01 & 4,03 & 6,69 & 41,01 & III \\
\hline 20 & Karanganom & 4,94 & 32,02 & 7,59 & 13,26 & 57,81 & II \\
\hline 21 & Tulung & 6,22 & 36,89 & 2,65 & 8,31 & 54,07 & II \\
\hline 22 & Jatinom & 8,89 & 34,41 & 7,20 & 12,38 & 62,88 & II \\
\hline 23 & Kemalang & 4,49 & 17,67 & 5,26 & 4,07 & 31,49 & III \\
\hline 24 & Klaten Selatan & 13,88 & 36,00 & 17,12 & 13,95 & 80,95 & I \\
\hline 25 & Klaten Tengah & 20,00 & 45,00 & 20,00 & 11,86 & 96,86 & I \\
\hline 26 & Klaten Utara & 16,20 & 40,88 & 10,60 & 14,65 & 82,33 & I \\
\hline
\end{tabular}

\section{Sektor Basis di Pengembangan Wilayah Kabupaten Klaten}

Sektor basis merupakan penggerak utama dalam perekonomian suatu wilayah. Semakin banyak sektor basis dalam suatu wilayah akan menambah arus pendapatan ke wilayah tersebut. Sektor basis Kebupaten Klaten terbagi kedalam lima sektor basis yaitu, pertanian, industri, perdagangan, angkutan dan jasa. Analisis sektor basis digunakan untuk menentukan sektor unggulan atau ekonomi basis suatu perekonomian wilayah. Sektor unggulan yang berkembang baik mempunyai pengaruh yang signifikan terhadap pertumbuhan ekonomi suatu wilayah dan akhirnya dapat meningkatkan pendapatan daerah secara optimal.

Sektor Pertanian di Kabupaten Klaten didukung oleh banyaknya sumber daya lahan yang dapat digunakan sebagai sarana penunjang untuk meningkatkan hasil produksi pertanian. Luas lahan pertanian di kabupaten klaten pada tahun 2015 yang mencapai $60,55 \%$ membuat sektor pertanian memiliki kontribusi besar PRDB. Kecamatan Gantiwarno dan Kecamatan Karangnongko mendapatkan nilai sektor basis tertinggi di sektor pertanian dari tahun 2010-2015. Nilai sektor basis pada tahun 2015 menunjukkan sektor tersebut banyak menyerap tenaga kerja. 


\section{PETA PUSAT PERTUMBUHAN KABUPATEN KLATEN}

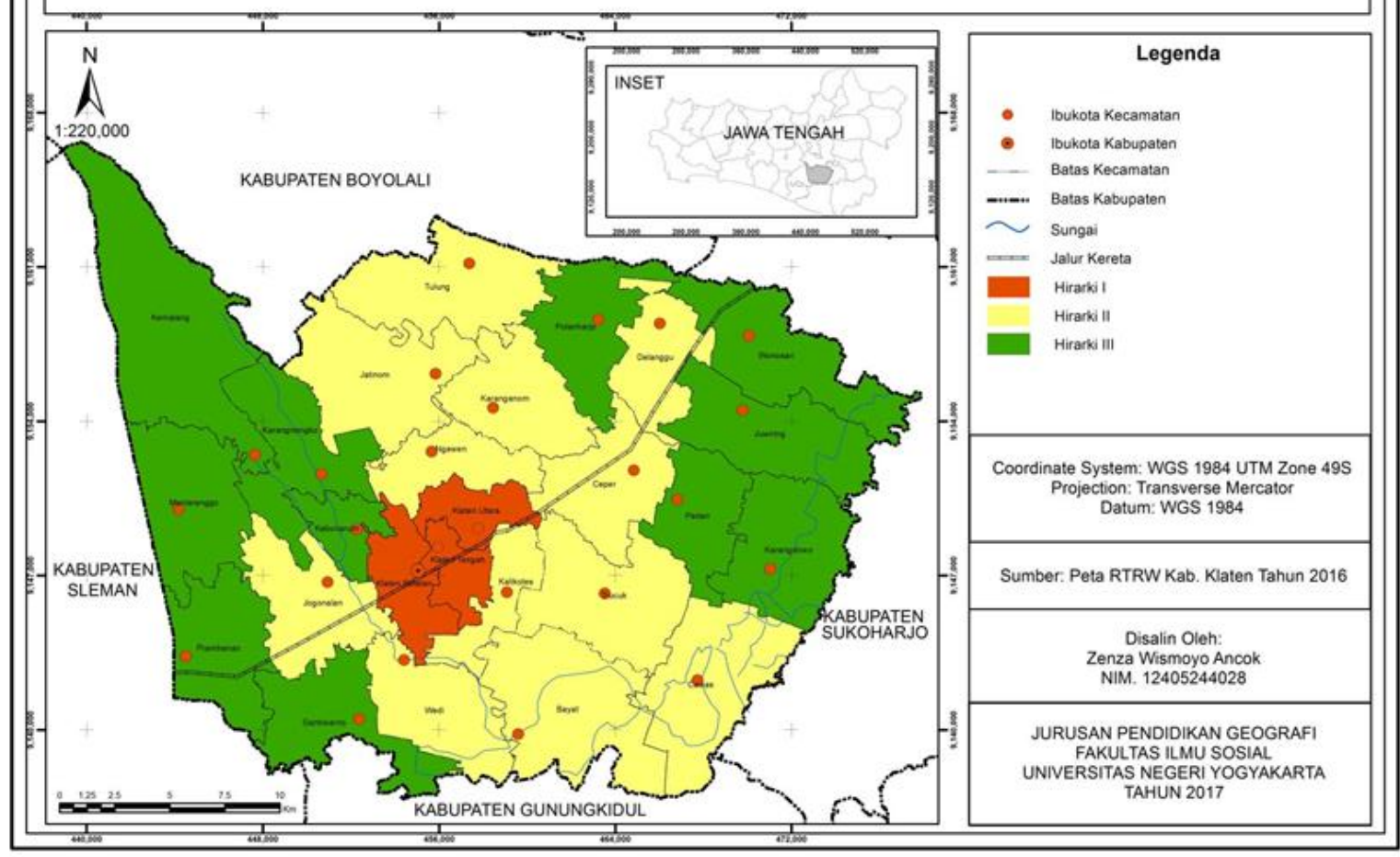

Gambar 3. Peta Pusat Pertumbuhan Kabupaten Klaten

Kecamatan Ceper, Polanharjo, Klaten Tengah dan Klaten Utara mendapatkan nilai rendah dalam 5 tahun terakhir. Sektor pertanian di beberapa daerah selama 2010-2015 mengalami penurunan jumlah tenaga kerja. Kondisi tersebut menggambarkan bahwa sebagian penduduk mulai meninggalkan sektor pertanian. Faktor utama yang mempengaruhi adalah nilai investasi yang besar di bidang industri dan pengolahan menyebabkan penyerapan tenaga kerja pada bidang ini juga semakin besar. Selain itu banyaknya alih fungsi lahan pertanian menjadi pemukiman juga menjadi penyebab semakin berkurangnya lahan pertanian.

Sektor basis industri dan pengolahan tertinggi berada di Kecamatan Ceper $(2,55)$. Kecamatan Ceper memiliki jumlah penduduk dengan pekerjaan di sektor industri pengolahan sebesar 4325 (15,84\%) dari seluruh pekerja sektor industri pengolahan di Kabupaten Klaten. sektor perdagangan sebagian besar mengalami peningkatan antara tahun 2010-2015. Wilayah dengan potensi sektor perdagangan yaitu Kecamatan Wedi, Cawas, Kalikotes, Pedan, Karangdowo, Tulung, Jatinom, Kemalang dan Klaten Tengah.
Dari sektor angkutan, Kecamatan yang memiliki nilai sektor basis angkutan tertinggi adalah Kecamatan Bayat. Jumlah tenaga kerja yang terserap di sektor angkutan pada tahun 2015 mencapai 1099 pekerja. Wilayah dengan keunggulan sektor jasa yaitu Kecamatan Gantiwarno, Cawas, Trucuk, Jogonalan, Ngawen, Karangdowo, Wonosari, Delanggu, Polanharjo, Karanganom, Jatinom, Klaten Selatan, Klaten Tengah dan Klaten Utara. Kecamatan Klaten Utara memiliki jumlah sektor basis pada sektor jasa tertinggi di Kabupaten Klaten sebesar 1382 pekerja. Kecamatan Klaten Utara memiliki keunggulan lokasi yang mudah di jangkau karena berada di pusat kota. Selain itu keterdapatan sekolah dan perguruan tinggi seperti Universitas Widya Dharma menjadi salah satu daya tarik tersediri bagi masyarakat untuk lebih berkembang di sektor jasa.

\section{Arahan Pengembangan Wilayah Kabupaten Klaten}

Arahan Pengembangan dengan memperhatikan sebaran fenomena keruangan pada masing-masing wilayah Kecamatan di Kabupaten Klaten. Sebaran fenomena keruangan 
meliputi tingkat aksesibilitas wilayah kecamatan, ketersediaan berbagai fasilitas pelayanan publik, potensi penduduk, dan keterkaitan wilayah antar kecamatan.

Pusat pertumbuhan utama di Kabupaten Klaten terdapat di kawasan perkotaan Klaten (Kecamatan Klaten Selatan, Kecamatan Klaten Tengah dan Kecamatan Klaten Utara). Keunggulan wilayah perkotaan yang paling jelas adalah memiliki wilayah yang strategis dengan tingkat aksesibilitas tinggi. Selain kedua faktor tersebut, penentuan sebagai pusat pertumbuhan juga didukung dengan berbagai macam fasilitas publik yang tersedia sehingga sangat cocok digunakan sebagai pusat pertumbuhan utama.

Pusat pertumbuhan alternatif di Kabupaten Klaten terdapat di Kecamatan Wedi, Bayat, Cawas, Trucuk, Kalikotes, Jogonalan, Ngawen, Ceper, Delanggu, Karanganom, Tulung, dan Jatinom. Kecamatan tersebut memiliki potensi untuk dapat berkembang menjadi pusat pertumbuhan baru. Arahan pertumbuhan sektor basis dapat berperan penting dalam meningkatkan pendapatan ekonomi wilayah.

Sektor Pertanian berada di Kecamatan Wedi, Bayat, Cawas, Trucuk, Kalikotes, Jogonalan Karanganom, Tulung dan Jatinom. Kecamatan tersebut memiliki wilayah luas yang dapat digunakan sebagai lahan pertanian. Pemanfaatan lahan akan didukung dengan penggunaan teknologi pertanian modern sehingga dapat meningkatkan pendapatan dari sektor pertanian.

Kecamatan Wedi, Kecamatan Ceper dan Kecamatan Delanggu diarahkan kepada sektor industri. Sektor industri yang didukung stakeholder dapat memberikan dampak besar dalam perekonomian. Sektor industri juga dapat dijadikan sebagai sarana penyerap tenaga kerja yang efektif untuk meningkatkan pendapatan ekonomi.

Kecamatan yang direncanakan menjadi sektor perdagangan adalah Kecamatan Wedi, Cawas, Kalikotes, Tulung dan Jatinom. Kecamatan tersebut memiliki letak yang cukup strategis terutama Kecamatan Wedi, sehingga dapat dijadikan sarana untuk meningkatkan pendapatan ekonomi. Sektor Angkutan berada di Kecamatan Bayat, Kalikotes, Ngawen, Ceper, Tulung dan Jatinom. Sektor angkutan dapat dikembangkan dengan memperbanyak sarana transportasi. Sektor angkutan akan mempermudah mobilitas antar wilayah.

Sektor jasa sangat dipengaruhi oleh jumlah penduduk dalam suatu wilayah. Sektor jasa cocok dikembangkan di Kecamatan Cawas, Trucuk, Jogonalan, Ngawen, Delanggu, Karanganom dan Jatinom. Sektor tersebut dapat dikembangkan dengan menambahkan berbagai macam fasilitas pendidikan dan kesehatan di kecamatan tersebut.

Berdasarkan hasil analisis selanjutnya dapat disusun arahan pengembangan wilayah di Kabupaten Klaten. Kota Klaten diarahkan untuk pengembangan pada sektor jasa dan perdagangan di dukung dengan adanya arahan pengembangan di RTRW dengan pengembangan terminal penumpang tipe $A$ dan pengembangan terminal barang. Kota Klaten juga ditetapkan sebagai kawasan strategis ekonomi sehingga sangat sesuai dengan arahan pengembangan dalam sektor perdagangan. Sektor jasa dan perdagangan dapat mudah dikembangkan dengan jalur konektivitas dan fasilitas transportasi yang baik.

Kecamatan Bayat dikembangkan pada sektor pertanian dan angkutan didukung dengan pengembangan dan pengelolaan rawa jombor. Pengembangan dan pengelolaan rawa jombor sangan bermanfaat dalam ketersediaan sumber air irigasi pertanian. Pengembangan dan pengelolaan rawa jombor juga dapat digunakan sebagai pendukung pengembangan sektor angkutan, karena rawa jombor juga dapat dijadikan objek wisata sehingga perlu adanya fasilitas transportasi salah satunya angkutan. Penetapan kawasan peruntukan industri kecil di RTRW tidak didukung dengan sektor basis industri pengolahan yang masuk ke dalam sektor non basis.

Kecamatan Tulung dan Jatinom dikembangkan pada sektor pertanian, perdagangan, dan angkutan. Pengembangan di sektor pertanian didukung dengan ketersediaan lahan pertanian yang luas (1738 Ha). Penetapan kawasan strategis gunung berapi dan sekitarnya di RTRW menjadikan daerah Kecamatan Tulung dan Jatinom menjadi subur dan sangat cocok digunakan untuk pertanian.

Arahan pengembangan di Kecamatan Delanggu berupa pengembangan pada sektor industri dan jasa. Pengembangan pada sektor 
industri didukung dengan penetapan di RTRW sebagai kawasan strategis ekonomi. Penetapan kawasan strategis agropolitan di RTRW tidak didukung dengan jumlah tenaga kerja pada sektor pertanian yang mulai beralih ke sektor jasa.

Kecamatan Wedi dan Karanganom diarahkan untuk dikembangkan pada sektor industri dan perdagangan. Kondisi tersebut didukung dengan penetapan Kecamatan Wedi dan Karanganom sebagai kawasan strategis ekonomi dan kawasan peruntukan industri besar di RTRW. Kecamatan Ceper diarahkan pada pengembangan sektor industri dan angkutan didukung dengan arahan kebijakan RTRW yang menetapkan sebagai kawasan strategis ekonomi.

Kecamatan Ngawen dikembangkan pada sektor pertanian, angkutan dan jasa. Pengembangan sektor pertanian didukung dengan penetapan Kecamatan Ngawen sebagai kawasan agropolitan di RTRW. Kecamatan Cawas dikembangkan pada sektor pertanian, perdagangan dan jasa. Sektor perdagangan didukung dengan penetapan Kecamatan Cawas sebagai kawasan strategis ekonomi di RTRW. Kecamatan Kalikotes diarahkan dikembangkan pada sektor pertanian, perdagangan dan angkutan. Pengembangan kawasan perdagangan didukung dengan penetapan di RTRW dengan arahan pengembangan kawasan strategis ekonomi. Kecamatan Trucuk dan Jogonalan dengan arahan pengembangan di sektor pertanian dan jasa. Pengembangan di sektor pertanian di Kecamatan Jogonalan didukung dengan penetapan sebagai kawasan agropolitan di RTRW. Penetapan kawasan strategis ekonomi di Kecamatan Trucuk tidak di dukung dengan jumlah tenaga kerja pada sektor industri yang mayoritas berada pada sektor pertanian dan jasa.

\section{Simpulan}

Berdasarkan hasil analisis dapat ditentukan arahan pengembangan wilayah di Kabupaten Klaten. Kawasan perkotaan Klaten dapat diarahkan sebagai sebagai pusat pertumbuhan utama. Kecamatan Wedi, Bayat, Cawas, Trucuk, Kalikotes, Jogonalan, Ngawen, Ceper, Delanggu, Karanganom, Tulung dan Jatinom sebagai pusat pertumbuhan alternatif dan sisanya sebagai hinterland.
Berdasarkan hasil analisis dengan menggunakan metode $L Q$ diperoleh 16 kecamatan yang menjadi prioritas untuk dikembangkan sebagai wilayah pertanian, sedangkan 9 kecamatan diprioritaskan untuk sektor industri. Sektor industri yang berkembang akan berpengaruh terhadap pembangunan wilayah terutama infrastruktur dan budaya masyarakat. Pergeseran budaya masyarakat dari pedesaan ke perkotaan dapat berdampak pada peningkatkan sektor perdagangan, angkutan dan jasa yang akan ikut berkembang.

Identifikasi kesesuaian arahan pengembangan dengan RTRW Kabupaten Klaten menunjukkan bahwa Kota Klaten yang merupakan Pusat Pertumbuhan Utama diarahkan untuk pengembangan sektor jasa dan perdagangan. Pusat Pertumbuhan Alternatif meliputi, Kecamatan Bayat dikembangkan pada sektor pertanian dan angkutan. Kecamatan Tulung dan Jatinom dikembangkan pada sektor pertanian, perdagangan dan angkutan umum. Arahan pengembangan Kecamatan Delanggu berupa pengembangan pada sektor industri dan jasa. Kecamatan Wedi dan Karanganom dikembangkan pada sektor industri dan perdagangan. Kecamatan Ngawen dikembangkan pada sektor pertanian, angkutan dan jasa. Kecamatan Cawas pada sektor pertanian, perdagangan dan jasa. Kecamatan Kalikotes diarahkan untuk dikembangkan pada sektor pertanian, perdagangan dan angkutan. Kecamatan Trucuk dan Jogonalan dengan arahan pengembangan sektor pertanian dan jasa.

\section{Ucapan terima kasih}

Penelitian ini dapat terlaksana atas bantuan berbagai pihak. Untuk itu penulis mengucapkan terima kasih kepada seluruh pihak yang telah membantu dalam penelitian ini baik pengumpulan data maupun analisis data. Ucapan terima kasih secara khusus disampaikan kepada Pemerintah Kabupaten Klaten atas ijin penelitian dan data bagi penelitian ini.

\section{Referensi}

Bintarto dan Hadikusumo, S. 1979. Metode Analisis Geografi. Jakarta: LP3ES.

Badan Pusat Statistik Kabupaten Klaten. (2013). Kabupaten Klaten Dalam Angka 2013. Klaten: BPS. 
Badan Pusat Statistik Kabupaten Klaten. (2015). Muta'ali, L. (2015). Teknik Analisis Regional untuk Kabupaten Klaten Dalam Angka 2015. Klaten: BPS.

Perencanaan Wilayah, Tata ruang dan Lingkungan. Yogyakarta: BPFG UGM

Muta'ali, L. (2014). Perencanaan Pengembangan Wilayah Berbasis Pengurangan Resiko Bencana. Yogyakarta: BPFG UGM 